$\begin{array}{r}\text { Volume and Issues Obtainable at Center for Sustainability Research and Consultancy } \\ \text { Journal of Business and Social Review in Emerging Economies } \\ \text { ISSN: 2519-089X (E): 2519-0326 } \\ \text { Volume 6: No. 4, December } 2020 \\ \text { JSRC } \\ \text { Journal homepage: www.publishing.globalcsrc.org/jbsee } \\ \hline\end{array}$

\title{
Extent of Integration in Agriculture Supply Chain: The Public Sector Stakeholders Perspective
}

\author{
${ }^{\mathbf{1} N a d i r}$ Munir Hassan, ${ }^{2}$ Muhammad Nauman Abbasi \\ ${ }^{1}$ Department of Business Administration, Air University, Multan, Pakistan, nadir.magsi@aumc.edu.pk \\ ${ }^{2}$ Institute of Management Sciences, Bahauddin Zakariya University, Multan, Pakistan, \\ abbasimna@bzu.edu.pk
}

\begin{tabular}{l}
\hline ARTICLE DETAILS \\
\hline History \\
Revised format: November \\
2020 \\
Available Online: December \\
2020 \\
\hline Keywords \\
Supply Chain Integration, \\
Extent of Supply Chain \\
Integration, Agri Food Value \\
Chain, Network Perspective, \\
Supply Chain Performance.
\end{tabular}

JEL Classification

MO, M14

\begin{abstract}
Purpose: Integrating network factors (i.e. Actors, Activities, and Resources), help organizations in achieving superior supply chain performance. Despite reasonable evidence on positive relationship between SCI and SCP, there exists sufficient contradiction on universal integration of chains. This paper is a qualitative exploratory study, which based on the network perspective intends to explore the current and required levels of supply chain integration among actors, activities, and resources in the agriculture supply chain of Pakistan. Design/Methodology/Approach: The data was collected through in depth semi-structured interviews from public sector stake holders of agriculture sector (i.e. From Thirteen wings of Ministry of Agriculture) across Pakistan. The current and required extent of supply chain integration was measured at three levels, i.e. strategic (long-term), tactical (medium-term) and operational (short-term) as suggested by (Childerhouse \& Towill, 2011). Findings: The research results indicate that the relationship between supply chain integration and supply chain performance is a contextual phenomenon and significantly varies among Network factors. This study and its findings are expected to add into the literature of supply chain integration and its impact on supply chain performance.
\end{abstract}

(C) 2020 Center for Sustainability Research and Consultancy Pakistan under a Creative Commons Attribution-NonCommercial-ShareAlike

4.0

Corresponding author's email address: abbasimna@bzu.edu.pk

Recommended citation: Hassan, N. M. \& Abbasi M. N. (2020). Extent of Integration in Agriculture Supply Chain: The Public Sector Stakeholders perspective. Journal of Business and Social Review in Emerging Economies, 6(4), 1335-1351

\section{Introduction}

The term 'supply chain management' reflects the flow of information, materials, money and products from both within and across the supply chains, starting from public sector stakeholders to final customers, in pursuit of achieving lasting performance (Mentzer, Flint, \& Hult, 2001). Over the years, managing supply chains have attained fabulous attention by both academicians and practitioners. Most 
recently, it has been defined as the set of tools and techniques used for managing supply chain activities for effective coordination to improve overall supply chain performances (Kusi-Sarpong, Sarkis, \& Wang, 2016; Liu, Bai, Liu, \& Wei, 2017). The significance of integration between actors, activities and resources of a supply chain has become indispensable for the survival of the firms. In today's highly competitive world, it is evident that businesses compete as supply chains rather than as stand-alone companies (Christopher, 2016).

The concept of 'integration' is a vital facet of supply chain management. Surprisingly, the outcomes of previous studies does not authenticate the universal (only positive) relationship between SCI and SC performance. For example, (Flynn, Huo, \& Zhao, 2010) and (Germain \& Iyer, 2006) explained that there exists sufficient clarity on potential positives of SCI yet a number of researchers are of the view that there exists reasonable inconsistency in findings related to its impact on supply chain performance. Likewise, many researchers are of the view that the benefits generated from integration might not be generalized rather remained contextual in nature (Turkulainen, 2008; Wong, Boon-Itt, \& Wong, 2011).

Interestingly, scholars have conceptualized and measured SCI differently, including strength, scope (Fawcett \& Magnan, 2002; Flynn et al., 2010; Frohlich \& Westbrook, 2001), duration and/or depth across the chains. Researchers have also identified that integration among the number of individuals on multiple hierarchical stages and from different corporate standings makes the integration work better (Barnes, Naudé, \& Michell, 2007; Mackelprang, Robinson, Bernardes, \& Webb, 2014). Furthermore, it also evident from the literature that for the exceptional gains, supply chains must be managed as networks. The network is a flat organization form, involving interaction among network partners rather than multi-layered functions (Cravens \& Piercy, 1994). Networks as cited by (Harland, 1996), consist of factors like, actors, resources and activities, which if integrated properly can cause sufficient supply chain performance.

Most recently, Wong et al. (2011) recommended, the need for additional research on the interaction between supply chain performance and dimensions of SCI, and also the effect of additional contingencies on SCI. Similarly, Tarifa-Fernandez and De Burgos-Jiménez (2017) expressed that it's time to understand and conduct research on SCI and its relation with performance concerning contextual factors, under which it will work more effectively. Accordingly, this study aimed to explore the variant levels of supply chain integration among actors, activities, and resources in agriculture supply chains. Based on the network perspective, this study identifies the role of agri-based public sector stakeholders in attaining the desired extent of integration with some of their key supply chain members, particularly, farmers and input suppliers. It is believed that knowing the desired extent (current and required) of integration will not only help to depute resources accordingly rather it will also help to maximize supply chain performance. To our utmost knowledge, no such research has been conducted earlier to address this critical gap especially with reference to Pakistan and hence the outcomes of this study provide valuable insights to all relevant stakeholders, i.e. academia, practitioners and policymakers.

\section{Literature Review}

Ever rising operational complexities for firms, shrinking product life cycles, and an increased desire for improved customer service has brought the attention of scholars and researchers towards understanding the concept of supply chain management (SCM) (Davis, 1993). Likewise, back in the 1990's, companies started to identify their business environment from the supply chain perspective and to build effective supply chains that operate according to the best SCM practices (e.g. Stevens (1989). Since, the term SCM coined in the literature (Handfield \& Nichols, 2002; Oliver \& Webber, 1982; Stevens, 1989), researchers are consistently investigating its different aspects.

To proceed with, Bechtel and Jayaram (1997) categorized supply chain literature into four school of thoughts, which includes; The functional chain awareness school, The linkage school, The information school and The integration/process school. Among these four, integration schools gain fabulous 
attention by the majority of the researchers. For example, (Mentzer, DeWitt, et al., 2001), while explaining integration school, have classified supply chains as direct, extended, and ultimate supply chains. It was anticipated that besides increasing supply chain alliances and integration, coordination initiatives are expected to move beyond internal linkages, towards the establishment of a connection between suppliers, customers and then supply networks. This reflects the origination of seeing supply chains from linear relations to more dynamic and complex relations like networks.

\subsection{Network Perspective}

A network is a system shaped by core factors (e.g. actors, activities and resources) that join the number of linked firms (Jraisat, 2016). A network is referred to as a set of links among a group of actors (Jarillo, 1988; Jarosz, 2000; Ritter \& Gemünden, 2004), and these links cause connections with other network factors to provide with a two-way interaction for overall performance. Most of earlier researches, for example, (Anderson, Håkansson, \& Johanson, 1994; Koops, Mollenkopf, \& Zwart, 2002; Ritter \& Gemünden, 2004) state the need for effective management of key network factors including actors, activities, and resources and interaction between these to generate even better positives. This depicts, to manage the supply chains successfully, one will have to see chains from the prism of network perspective. Moreover, to make the supply chain networks work proficiently, there is a definite need to observe the interaction among network components. For example, Wilson (1995), Mikkola (2008) and Sluyts, Matthyssens, Martens, and Streukens (2011) considered value chains as supply networks and suggested it as a source of competitive advantage.

However, research has been scarce regarding the appropriate extent of integration within supply chain networks, and that, networks without being integrated won't generate the expected outcomes.

\subsection{Supply Chain Integration (SCI) and Supply Chain Performance (SCP)}

Supply chain integration (SCI) is defined as the extent to which a firm strategically collaborates with its supply chain members and collaboratively administrates intra- and inter-organizational processes (Flynn et al., 2010). SCI reflects the multi-organizational networks in sync with governing the flow of products, services, information and finances from top to bottom (Ellram \& Cooper, 2014). Likewise, from the lens of information processing theory, SCI becomes the source of better quality, and well versed decision making, by making stakeholders within firms and across chains to communicate effectively (Hendijani \& Saei, 2020). Without any doubt SCI has appeared to be the key theme (Lee and Billington (1992) and making the researchers to dig deep into the concept and to better understand its connection with SCP.

Interestingly, speculating what must be integrated, and how it must be integrated directs one to reason the difficulty associated with defining the given concept of SCI (Mohamed \& Hassan, 2019). In literature, it is observed as a unidimensional (Cousins \& Menguc, 2006) as well as a multidimensional construct (Morash \& Clinton, 1998; Stank, Keller, \& Daugherty, 2001). Furthermore, researchers have realized the strategic importance of SCI and have empirically observed the interaction between multiple aspects of SCI and several performance streams (Devaraj, Krajewski, \& Wei, 2007; Frohlich \& Westbrook, 2001; Schoenherr \& Swink, 2012). In present-day business settings, integration is regarded as a viable strategy for individuals, firms and industries looking for sufficient performances (Li \& Chen, 2018). While, to better implement, integration must widely be considered as a multidimensional variable (Flynn et al., 2010), because it incorporates cooperation, collaboration, information sharing and partnership, through functions, customers and suppliers.

Similarly, SCI is explained in terms of its scope, starting from the focal firm, internal processes, till external integration (Doering, De Jong, \& Suresh, 2019). To develop a better understanding and theoretical realities related to the concept of integration, (Autry, Rose, \& Bell, 2014) elaborates integration from operational coordination (i.e. activities in support of planning, information exchanges, and system integration) to tactical cooperation (i.e. recognition and achievement of mutually beneficial 
activities) and finally a strategic collaboration and integration (i.e. establishment and maintaining of collaborative relationships)..

Keeping in mind the changing scope and intensity of integration within and across supply chain networks, it has become equally important to observe the connection between different extents of integration and its impact on supply chain performance. For example, its believed, that an integrated supply chain not only helps in reducing the cost for a focal firm, rather it causes notable benefits for its channel members as well. Considering the importance of SCI and its domains, in making supply chain networks perform better, it is observed that usually successful firms are those that align their internal processes with external channel members and customers within their supply chains (Frohlich \& Westbrook, 2001; Graham, Zailani, \& Rajagopal, 2005). Similarly, aligning processes, also means, that, firms, that can assemble resources in a comparatively, different manner, may reap an advantage over firms, which aren't willing to do the same (Ganbold, Matsui, \& Rotaru, 2020).

Moreover, (Leuschner, Rogers, \& Charvet, 2013), based on a meta-analysis, observed a positive relationship between SCI and SCP whilst, other studies, witnessed inverse relationship. Similarly, to better understand supply chain performance, it is described as the strength of a supply chain to economically perform its activities, while reducing the cost of operations, with the ultimate goal of meeting customers and channel members desires (Green \& Inman*, 2005).

From literature, it is evident that one cannot measure supply chain performance from any single perspective or context, rather supply chains need to be considered, as a system and networks. Considering, the performance of all these activities and elements, across supply chain network, will help in reaching out to the full potential of overall supply chain performance (Rehman, Khan, Kusi-Sarpong, \& Hassan, 2018). In sync with these studies, (Zhao, Huo, Selen, \& Yeung, 2011) suggested that intensity/span of SCI between multiple dimensions of SCP can differ, because, it is a contextual phenomenon, and need to be reevaluated across value chains. Even though, a handful of researches have propagated a positive relationship between SCI and SCP, still there exists a gap in the given stream (Song, Song, \& Sun, 2019). Additionally, this study propagates that not all levels, extents and types of SCI are required to be made use of on all occasions. This understanding is in line with the research work of (Flynn et al., 2010), wherein, they suggested different configurations and arcs of SCI based on three broader dimensions, i.e. internal, supplier and customer integration.

According to a contingency perspective, manufacturers need to adopt a specific extent or arc of integration to synchronize specific dimensions of SCI with its environment (Visnjic, Wiengarten, \& Neely, 2016). Consequently, the configuration perspective states that performance is a product of consistency between different configurations of SCI, and its environment to reach required performance outcomes (Flynn et al., 2010). There are industries and sectors, like agricultural, automotive, chemical, textile, pharmaceutical, etc. which have different down and upstream dynamics, so players in such sectors might use different (Frohlich \& Westbrook, 2001) and unbalanced configurations of supply chain integrations (Flynn et al., 2010). Despite of considering the extensively worked, viewpoints on SCI and its impact on SCP, it is important to realize that results on the above given relationship are still relatively inconclusive. This lack of clarity is because of the different outcomes generated by selecting multiple dimensions of integration and performance (Wiengarten, Li, Singh, \& Fynes, 2019). This is why the given study explores the appropriate extent of SCI among AVC's channels members.

For the given purpose, this study incorporates, four primary elements \& multiple extent of integration to measure the current \& required level of integration among network components, i.e. actors, activities, and resources. The aim is to provide a theoretical foundation for measuring the benefits bestowed by optimal level of SCI on the overall performance of AFVC in Pakistan. Unfortunately, identifying an optimal level of integration remained a neglected area especially regarding network perspective, which is assumed to be one of the identifiable reasons behind overall agricultural performance across the 
country.

\subsection{SCI and Agri-Food Value Chain}

Pakistan is an agriculture based country with 23.4 million hectares cultivable land and is among the largest producer and supplier of many agri-products, like, cotton, wheat, sugarcane, mango, citrus, oranges, oilseeds, rice, etc. During 2017-18, agriculture sector observed a remarkable growth of 3.81\% as compared to previous years $(2016-17 ; 2.07 \%)$ and $(2015-16 ; 0.15 \%)$ (Economic Survey of Pakistan, 2017-18). This stemmed from higher yields, fertilizer take off, pest control, etc. however, the real credit goes to the government policies and initiatives, like, availability of quality seed, attractive prices, credit facilities, trainings and guidance, etc. Unfortunately, Pakistani agriculture/food supply chain is quite vulnerable and it lack innovation, value addition, new product development, packaging and marketing. Such, a fragmented structure sheds light on the need for the appropriate implementation of integration among agri-food value chain. Nonetheless, the presence of private sector is somewhat encouraging as they are striving hard to integrate activities related to collection, transportation, storage, assembling within and outside the country.

A number of scientific studies have favored the need for vertical integration of agribusiness activities, and its role in decreased production cost, among channel members of the agricultural supply chain (Birthal, Joshi, \& Gulati, 2005). On the other hand, Porter (1985) states that competitive advantage within the agricultural supply chain is vested in networking by chain actors. The multi-dimensional performance of agri-food chains is purely a product of contextual supply chain configuration i.e. the insight into the type and where about of network factors and their integrated flow (de Keizer et al., 2017).

However, realizing the sufficient level of SC-SCI configuration for agri-food chains is a complicated issue, due to certain ingrained complexities associated with food products and processes (Soto-Silva, Nadal-Roig, González-Araya, and Pla-Aragones (2016). The availability of a number of agri-oriented resources including, fertile land, well-irrigated plains and a variety of seasons makes Pakistan favorable for the agriculture industry. Yet, Kahn and Mentzer (1998), arguments regarding, scarcity of integration among various stakeholders in agri-chains, results in overall inefficiency of agricultural system, resulting in high post-harvest losses, quality deterioration, and high cost of commodity transfer, information symmetry and lack of transparency cannot be unnoticed.

The pace of adoption of SCI and responsiveness towards the needs of respective channel members of the agriculture chain in Pakistan, is passive in nature in comparison to prevailing trends elsewhere. That's why the given study, propagates the idea of understanding the importance of integration among network actors of AFVC in Pakistan, and that blind and mindless implementation of SCI can also result in unidentified cost of stakeholders. It means that it is unavoidable to develop a consensus on the required level of integration across the agricultural supply chain in Pakistan. Because it has widely been acknowledged, that the proactive approach towards integrative relationships can act as a vital source of competitive advantage for overall supply chains across the globe (Power, 2005) and agricultural value chains are no different.

\section{Research Methodology}

The given study aimed to get insight into the current and required level of SCI between public sector stakeholders and some of their key supply chain partners, i.e. input suppliers and growers, etc. Considering the contextual nature of supply chain integration, and differences in industrial norms (Kostova \& Roth, 2002), this study intends to conduct case study of agriculture public offices of Pakistan. Based on the network perspective, an attempt has been made to identify the role of agri-based public sector stakeholders in attaining desirous level of integration with their supply chain partners. The public sector stakeholders' perspective was recorded and analyzed to build an understanding of the impact of varying extent of SCI on the overall performance of the agriculture supply chains. 
As propagated by (R. Yin, 2003), case study method is frequently used as a data collection tool in practical fields like management. So, using the case study method, multiple participants of AFVC in Pakistan, were interviewed. The detail regarding participants is given in Table No. 1. Later on, interview data from one interviewee was triangulated with those from other interviews.

In the given study, SCI is operationalized and measured through information sharing, collaborative approaches, joint decision making and system coupling, as prescribed by (Ellinger, Keller, \& Hansen, 2006; Flynn et al., 2010; Narasimhan \& Das, 2001). Existing literature suggests, SCI as a multi-level longitudinal phenomenon and it evolves over an extended period. In this evolving process, supply chain partners interact with each other both in the internal and external business environment, which is also dynamic in nature. Therefore, there was a need to take into consideration the time orientation of the relationships (integration) which remained under observation. Hence, the case study method has been opted. It also helped us to present a detailed outlook of the phenomenon under study and also to describe the context in which it takes place (Halinen \& Törnroos, 2005). By opting for the technique of triangulating the multiple data sources, the data collection and analysis cover up the longitudinal dynamics of the SCI.

While, the extent of integration is measured through three levels, i.e. strategic, tactical, and operational across three dimensions of network perspective (Autry et al., 2014), i.e. activities, resources, and actors, i.e. public sector stakeholders, input suppliers and growers.

\section{Data Collection \& Analysis}

In line with the previous studies, R. K. Yin (2015), the respondents were thoughtfully selected to gain in-depth and diversified perspectives regarding the extent of integration between supply chain partners. The respondents were selected, only if he/she is directly involved and/or understand the organizational strategy regarding execution of integration with their channel members. In simple words, respondents of the given study can be labeled boundary spanners of the case offices. The normal time for each interview was around 60-90 minutes. Notes were taken to develop the interview reports. Ambiguous responses were clarified through a proper follow-up phone calls, and formal emails. Likewise, basic data was gathered from websites, news coverages and published material. The profiles of the companies, are as follows:

Table 1. Specifications of Respondents (Public Sector Stakeholders

\begin{tabular}{|l|l|l|}
\hline Public Office & Industry & Interviewee's Position \\
\hline $\begin{array}{l}\text { Directorate General Agriculture } \\
\text { (Water Management) }\end{array}$ & $\begin{array}{l}\text { Agriculture } \\
\text { Department of Punjab }\end{array}$ & Deputy Director \\
\hline Directorate General Agriculture (Field) & AD-GoP & Assistant Agricultural Engineer \\
\hline $\begin{array}{l}\text { Directorate General Agriculture } \\
\text { (Research), AARI, Faisalabad. }\end{array}$ & AD-GoP & Assistant Director \\
\hline $\begin{array}{l}\text { Directorate General Agriculture } \\
\text { (Pest Warning \& Quality Control of Pesticides) }\end{array}$ & AD-GoP & Assistant Director Agriculture \\
\hline Directorate General Agriculture (Extension \& AR) & AD-GoP & Deputy Director Agriculture \\
\hline $\begin{array}{l}\text { Directorate General Soil Survey of Punjab } \\
\text { Deputy Director General Soil } \\
\text { Survey of Punjab }\end{array}$ \\
\hline $\begin{array}{l}\text { Directorate of Agriculture (Economics \& } \\
\text { Marketing) }\end{array}$ & AD-GoP & EADA (E\&M) \\
\hline $\begin{array}{l}\text { Directorate of Agricultural (Information) } \\
\text { Federal Seed Certification and Registration } \\
\text { Department (FSC\&RD) }\end{array}$ & $\begin{array}{l}\text { Ainistry of National Food } \\
\text { Security and Research }\end{array}$ & $\begin{array}{l}\text { Assistant Agriculture Info. } \\
\text { Officer } \\
\text { Regional Director }\end{array}$ \\
\hline $\begin{array}{l}\text { Agriculture Policy Institute (API) } \\
\text { Corporation (PASSCO) }\end{array}$ & MNFS \& R & Director General \\
\hline Economic Wing & MNFS \& R & GM Field Wing \\
\hline National Fertilizer Development Centre (NFDC) & MNFS \& R & Economic Consultant \\
\hline
\end{tabular}


The content analysis was deployed for data analysis. Initially, data coding (an analytical tool, letting data indexed for analysis purpose, and linking it with the main research idea) was coupled with initial codes generated through themes extracted from literature review, observation, and by making use of interview manuscript. Likewise, the given process is followed by refinement of shortlisted themes, to avoid repetition.

Moreover, the process of coding and analysis resulted into 20 first order themes in order to measure the extent of SCI, which then resulted into even brief 15 second order themes, ending up into four aggregate dimensions. The comprehensive, dimensions extracted are the mechanisms/activities associated with SCI, helpful in forming theoretical relation with the given study. Table 2 , presents snapshot of $1^{\text {st }}$ order/sub-categories, $2^{\text {nd }}$ order/generic-categories and aggregated/main categories of SCI. 
Table 2. Data Coding: $\mathbf{1}^{\text {st }}, 2^{\text {nd }}$ Orders and SCI Themes

First-Order/Sub Categories Second-Order/Generic Themes

Aggregate/Main Themes (SCI)

\begin{tabular}{|c|c|c|}
\hline Integrated Information Sharing on new Agricultural Varieties. & \multirow[t]{2}{*}{ Creating Varieties \& Exportable Surplus } & \multirow[t]{5}{*}{ Information sharing } \\
\hline $\begin{array}{l}\text { Information Exchange regarding Sustainable Generation of } \\
\text { Exportable Surplus. }\end{array}$ & & \\
\hline Educating Stakeholders on Conservation of Natural Resources. & Sustainable Value Addition & \\
\hline Shared Technology, for Smooth flow of Information. & \multirow{2}{*}{$\begin{array}{l}\text { Shared Communication Technology for } \\
\text { Information Sharing on Researchable Issue }\end{array}$} & \\
\hline To Generate follow up on Researchable Issues/Problems. & & \\
\hline Improvement \& Transfer of Water Management Technology. & Water Management & \multirow[t]{7}{*}{ Collaborative Activities } \\
\hline Joint Development of Objectives and Responsibilities. & \multirow[t]{3}{*}{ Policy Making for Agricultural Growth } & \\
\hline $\begin{array}{l}\text { Joint Improvement of Marketing System to Ensure, Agricultural } \\
\text { Growth. }\end{array}$ & & \\
\hline Coming Together with Farmers in Regulatory Aspects. & & \\
\hline Collaborative Conduct of Research \& Development & Research \& Development & \\
\hline Mutual Adaption of Modern Agricultural Technology. & Technological Adaption & \\
\hline $\begin{array}{l}\text { Procurement, Processing, Production, Multiplication, Marketing } \\
\text { and Distribution of Quality Agricultural Inputs. }\end{array}$ & Provision of Quality Inputs & \\
\hline Joint Development of Logistics processes. & Logistics Management & \multirow[t]{4}{*}{ Joint Decision Making } \\
\hline $\begin{array}{l}\text { Anticipating \& Resolving their Operative/Emergent Field } \\
\text { Problems. }\end{array}$ & Advisory Services & \\
\hline Conservation of Resources through Renewable Tools. & On Field Sustainability & \\
\hline $\begin{array}{l}\text { To Contribute towards the Cost of any Experiment or Technical } \\
\text { Research related to Agriculture. }\end{array}$ & Research Financing & \\
\hline Harmonized Data Sharing to Manage Produce. & Strategic Reserves Management & \multirow{4}{*}{ System Coupling } \\
\hline Collaboration on Price Control of Agricultural Produce. & Pricing & \\
\hline Provision of Facilities, \& Establishment of New Markets. & \multirow{2}{*}{$\begin{array}{l}\text { New markets Development \& management } \\
\text { through Market Committee's }\end{array}$} & \\
\hline Governance Initiatives through on market committee's. & & \\
\hline
\end{tabular}




\section{Findings and Discussion}

This study intends to explore the current and required extent of SCI among actors, activities, and resources in the agriculture supply chain. Based on the network perspective, the given study explains the role of agri-based public sector stakeholders in attaining integration with their supply chain partners, i.e. growers and input suppliers.

\subsection{Supply Chain Activities: Extent of Integration with Farmers and Input Suppliers.}

As described earlier, the extent of SCI was measured among four supply chain activities, i.e. information sharing, joint decision making, collaborative activities, and system coupling. Next section, present a brief overview regarding the extent of integration on each supply chain activity.

\subsection{Information Sharing: Current \& Required Extent of SCI}

The information-sharing has always been at the cornerstone for achieving the required level of performance. Interviewers were asked to explain the current and required level of integration (in the context of information sharing) with growers and input suppliers.

It was revealed that different public sector stakeholders use different information sharing tools, however, commonly used are; regular seminars \& workshops, village-level training programs, published material, dedicated TV and Radio programs (3000 talks, 1500 agricultural messages, \& 2000 agricultural news bulletins/ per annum), documentaries (normally broadcast on a special event, like, agri-festival, KisanDost Mela, etc.), Agriculture Help Line (0800-15000 and 0800-29000), SMS-Email Alerts, Websites/Portals, and Social Media (Facebook, WhatsApp, YouTube, Twitter), etc. Furthermore, type of information sharing include, harvesting and post-harvest issues, pest control, yield output per hectare, irrigation related issues, agri-loans/agri-financing, marketing, agri-research related issues, and issues associated to execution of research output, etc. Additionally, it was pointed out that contact through relevant staff, including, field officers, agricultural engineers and agriculture researchers are maintained on a regular basis. To ensure smooth flow of information, public sector stakeholders schedule meetings of the Technical Advisory Board and Agriculture Task Force with farmers and input suppliers, once in three months and once a month respectively.

During interviews, Director of Agriculture Research, explained that;

"we share information regarding emerging varieties of crops, vegetables and fruits with relevant stakeholders quite frequently".

Likewise, Deputy Director at the Department of Agriculture Extension, disclosed that;

"..... our responsibility is to ensure seamless flow of information [on protecting plants from all forms of impure infringements to increase the yield for local consumption and export]".

Educating growers and input suppliers regarding adoption of emerging ways of plowing, use of appropriate inputs, and adoption of new technologies, like, use of plastic bags, cardboard, cushions, proper hygienic and insect-proof stores, environment-friendly logistics etc. were marked as mandatory activities for information sharing.

Similarly, Assistant Director, Department of Pest Warning \& Quality Control, comment that;

"they guide growers \& agri-dealers, on right selection, safe handling and effective use of suitable agricultural inputs, adoption of proper spraying method and integrated pest management techniques in collaboration with National Fertilizers Development Center, and Punjab Seed Corporation”.

In a similar tune, while explaining the role of the Department of Agriculture Marketing Information Service, Marketing Officer told that;

"we have been successful in establishing Agriculture Marketing Information Service (AMIS) to enhance the efficiency of agriculture marketing system through the provision of timely reliable and useful market 
information for all stakeholders".

Based on the above stated information and remarks of the interviewer's public sector stakeholders are successful in establishing integration at the Tactical level with growers, however, they feel it should be extended to the strategic level. Amazingly, integration with input suppliers was marked at a strategic level and recommended to be maintained.

\subsection{Collaborative Activities \& Joint Decision Making: Current \& Required Extent of SCI}

According to (Kahn \& Mentzer, 1998), collaboration, interaction and joint decision making are a couple of basic ingredients of integration, wherein, joint decision making is a shared settlement by which multiple departments and parties within and across the chain reflect their readiness to deal in interorganizational collaboration (Shou, Li, Park, \& Kang, 2017).

Encouragingly, public sector stakeholders involve growers and input suppliers in collaborative projects. Moreover, they engage them in decision making in areas like, procurement, processing, production, multiplication, research output, marketing and distribution of quality seeds. Some of the common collaborative projects include, National Program for Improvement of Watercourses in Pakistan (PhaseII), Pilot Testing of Innovative Technologies to improve Water Usage, Virtual Meetings, Crop Insurance, Establishment of Small Tree System (STS), etc.

In this regard, Regional Director FSC \& RD, told that;

"Department of Federal Seed Certification \& Registration in collaboration with Department of Punjab Seed Corporation, has established 27 field offices and laboratories throughout Pakistan ..... we welcome our partners [farmers and input suppliers] to visit these facilities and maximize their agri-output".

FSC\&RD is a third-party service provider and has the mandate to regulate the quality of seeds of various crops under the legal provisions. To promote water stewardship, Federal Water Management Cell and Directorate General of Water Management collaborate in policy formulation regarding land/infrastructure development.

During the interview, Deputy Director, Department of Agriculture Water Management revealed that; "..... with various small farmers, we are working together (especially in Punjab province) for the adoption of modern technology, that include, drip/sprinkler design, lift irrigation system design, LASER land leveling, tunnel farming, watercourse designing, irrigation scheduling, etc.”.

Adding further, he stressfully claimed that;

“..... togetherness will lead to the accomplishment of our core objective, i.e. more crop per drop ...... however, we [all partners] have to overcome our [financial and operational] constraints".

It is also worth noting that at the market level, the Department of Agriculture Economics \& Marketing has successfully introduced the digital rate board at 27 different locations in Punjab.

While, illustrating, one of the public officer comment;

"... to help them [farmers] to better manage their operative problems, we [Department of Adaptive Research] use outcomes of applied research".

For this purpose, eight Adaptive Research Farms and six adaptive research stations were established. As cost remained the major concern in applied research, public sector institutions like, Punjab Agriculture Research Board, Directorate of Agriculture Field and Research collaborate with private sector input suppliers and they jointly sponsor many research projects.

The above stated examples of joint decision making and co-investments (in some key projects) reflect 
strategic collaboration between public sector stakeholders and their supply chain partners, including some growers and input suppliers. Likewise, such success based stories demands a similar level of integration to be attained in other core areas like, transportation, storage, etc. as the same was highlighted during interviews.

\subsection{System Coupling \& Incentive Alignment: Current \& Required Extent of SCI}

To maximize the gains, coupling of production processes, such as continuous replenishment between manufacturers, just-in-time (JIT), and Kanban between manufacturers and their external partners have been frequently suggested. Such relation oriented spending in system coupling doesn't only enable the integration of both information and physical flows, rather it helps in increasing the trust and commitment between channel members, and resultantly intensifies the cooperative behavior (Lui, Wong, \& Liu, 2009).

When asked, about harmonized data sharing, for helping stakeholders in managing their produce, General Manager Field Wing, responded;

"we at the department of agriculture, storage and service corporation and agriculture economic wing, deal in the collection, compilation and dissemination of agricultural statistics in its quest to ensure national food security by maintaining strategic reserves of different food grain commodities providing the same to deficit provinces".

Adding further, he pointed out;

“.... it is our prime responsibility to ensure consistent supply [of food] to armed forces and maintain international food bank on behalf of the federal government".

In this regard, one of the exemplary initiatives is the establishment of "Agro Food Processing (AFP) Facility", wherein, departments help growers in finding markets for their crops/grains. They even engage the private sector to ensure its plausible distribution and consumption and to take all necessary measures to minimize agri-food wastage.

Similarly, Deputy Director, Department of Agriculture Economics and Marketing, shared that they have established market committees with the mandate to regulate the sale and purchase of agricultural produce, collection and dissemination of market information, provision of facilities to all stakeholders, enforce price control mechanisms, establish new markets (wherever required), guide and help farmers and input suppliers in adopting international food standards.

Despite of such efforts, still the current extent of integration stands at the tactical level with growers and operational with input suppliers. For better supply chain performance, strategic level has been recommended. Generally, it is believed that a higher level of integration can help to reap the real benefits. However, it can only be achieved, if all parties will willingly cooperate. Conversely, with input suppliers, both operational and tactical levels of integration were declared sufficient.

\subsection{Resource Sharing: Extent of Integration with Farmers and Input Suppliers}

The extent to which resources are joined by the channel members affects the overall performance and its outcomes across the chains (Christensen \& Klyver, 2006). In literature, resources have been classified into four groups i.e. physical resources (i.e. includes facilities that help the internal and external exchanges), financial resources (e.g. monetary support and new resources), personnel resources (e.g. expert opinions and guidelines) and informational resources (e.g. information dissemination both within and across channel members) (Ritter, 1999). It has been observed that actors share their resources in a way, which inspires the channel members in their relationship and helps them to reach their objectives and develop useful connections within the network (Jraisat, 2016).

During interviews, it was revealed that multiple resource sharing mechanisms have been established. For 
example, the Department of Agriculture Extension, under the "Kitchen Gardening Program" provide subsidized seed kits to growers at approachable places. Similarly, the Department of Agriculture Extension \& Adaptive Research provides trainings on different topics to both growers and input suppliers for their capacity building. Likewise, state-of-the-art and well-equipped laboratories with the latest technologies have been established in eight (08) divisions and twenty-eight (28) districts of Punjab. Farmers and input suppliers can avail laboratory facilities for various analyses regarding plants, pests, soil and water resources. In addition to advisory services, agri-equipment, like, land levelers, bulldozers and other agri-utensils are being provided to growers under the Directorate of Agriculture Field. To strengthen collaboration, the Department of Farm Water Management guide efficient usage of water reserves, reduction of water evaporation, control on operational losses and water seepage, etc. Another valuable contribution is the installation of Digital Rate Boards in twenty-seven (27) different markets.

Table 3. Portray interesting insights regarding the extent of integration between public sector stakeholders, farmers and input suppliers.

\begin{tabular}{|c|c|c|c|c|c|c|c|c|c|c|c|c|}
\hline \multicolumn{13}{|c|}{ Table 3. Extent of Integration Concerning Resources } \\
\hline $\begin{array}{l}\text { NATURE OF } \\
\text { RESOURCES }\end{array}$ & \multicolumn{3}{|c|}{ PHYSICAL } & \multicolumn{3}{|c|}{ FINANCIAL } & \multicolumn{3}{|c|}{ PERSONAL } & \multicolumn{3}{|c|}{ INFORMATIONAL } \\
\hline \multirow{6}{*}{$\begin{array}{l}\text { SHARED } \\
\text { WITH } \\
\text { FARMERS }\end{array}$} & \multicolumn{12}{|c|}{ Current level of SCI } \\
\hline & $\overline{\mathbf{S}}$ & $\overline{\mathbf{T}}$ & $\overline{\overline{\mathbf{O}}}$ & $\overline{\mathbf{S}}$ & $\bar{T}$ & $\overline{\mathbf{O}}$ & $\overline{\mathrm{S}}$ & $\bar{T}$ & $\overline{\mathbf{O}}$ & $\overline{\mathbf{S}}$ & $\overline{\mathbf{T}}$ & $\overline{0}$ \\
\hline & & $\overline{\bar{\checkmark}}$ & & & & $\overline{\bar{\checkmark}}$ & $\overline{\bar{\checkmark}}$ & & & $\overline{\bar{\checkmark}}$ & & \\
\hline & \multicolumn{12}{|c|}{ Required level of SCI } \\
\hline & $\mathbf{S}$ & $\mathbf{T}$ & $\overline{\mathbf{O}}$ & $\bar{S}$ & $T$ & $\overline{\mathbf{O}}$ & $\mathbf{S}$ & $\mathbf{T}$ & $\overline{\mathbf{O}}$ & $\bar{S}$ & $\bar{T}$ & $\mathbf{O}$ \\
\hline & $\overline{\bar{\checkmark}}$ & & & & $\overline{\bar{\checkmark}}$ & & $\overline{\bar{\checkmark}}$ & & & $\overline{\bar{V}}$ & & \\
\hline \multirow{6}{*}{$\begin{array}{c}\text { SHARED } \\
\text { WITH INPUT- } \\
\text { SUPPLIERS }\end{array}$} & \multicolumn{12}{|c|}{ Current level of SCI } \\
\hline & $\mathbf{S}$ & $\mathbf{T}$ & $\mathbf{O}$ & $\mathbf{S}$ & $\mathbf{T}$ & O & $\mathbf{S}$ & $\mathbf{T}$ & O & $\mathbf{S}$ & $\mathbf{T}$ & $\mathbf{O}$ \\
\hline & & $\bar{\checkmark}$ & & & $\overline{\bar{\checkmark}}$ & & $\overline{\bar{\checkmark}}$ & & & $\bar{\checkmark}$ & & \\
\hline & \multicolumn{12}{|c|}{ Required level of SCI } \\
\hline & $\mathbf{S}$ & $T$ & $\overline{\mathbf{O}}$ & $\bar{S}$ & $\overline{\mathbf{T}}$ & $\overline{\mathbf{O}}$ & $\bar{S}$ & $\bar{T}$ & $\overline{\mathbf{O}}$ & $\bar{S}$ & $\overline{\mathbf{T}}$ & $\mathbf{O}$ \\
\hline & & $\sqrt{ }$ & & & $\bar{\checkmark}$ & & & $\bar{\checkmark}$ & & & $\bar{\checkmark}$ & \\
\hline
\end{tabular}



Despite of above measures, the management of public sector stakeholders believes that at present resource sharing with farmers and input suppliers is restricted at the tactical level. While, answering the question that integration should be extended to the strategic level? The majority of respondents were of the views that the desired results can be attained by engaging farmers in collaborative projects, however, they seem satisfied with the level of integration with input supplier Commenting further, Assistant Director [AE\&AR], pinpointed;

"that directorates and the connected departments working under the Department of Agriculture, Punjab desire to strengthen weaker partners, i.e. farmers as compared to established input suppliers. However, any worth mentioning collaborative project by input supplier can be welcomed".

In addition to physical resource sharing, the debates regarding integration for financial resources depict that due to financial constraints, farmers are far away from research initiatives. Though, Punjab Agriculture Research Board provides funds for research activities still the management believe that funding is not sufficient to fulfill the need of the farmers across the province. However, to increase agriinput, soft loans are being provided to farmers along with necessary information/education to adopt emerging technologies including drip irrigation, tunnel farming, etc.

To gain success, the Punjab Government sponsor 10,000/- rupees per acre for water storage ponds. Additionally, some projects, like, Punjab Irrigated-Agriculture Productivity Improvement Project, National program for improvement of watercourses in Pakistan, High-Efficiency Irrigation System (government subsidizes 60 percent of total system cost for installation of HEIS on up to 15 acres, while, the remaining costs are contributed by the beneficiary farmers) are hallmark projects and reflect the tactical level of integration between public sector stakeholders and farmers. On the other hand, agriinput suppliers also seem active. They sponsor basic farming (limited level), offer discounts to farmers, conduct seminars, organize workshops and festivals and take research initiatives. Additionally, logistics support, stocking, dealing and negotiation with wholesalers are some other financial support extended by input suppliers. Such financial collaborations between AFVC helps in generating overall supply chain performance. It is further revealed that designated employees including, directors, assistant directors, agriculture officers, agricultural engineers, field officers/staff remain in touch with key players on multiple levels and layers of the agriculture value chain. For example, agricultural officers and field assistants engage farmers on a daily basis for training, advisory services, sample collection for soil and water, pest scouting, distribution of seed kits, etc. One of the Director added;

"..... they ensure a seamless and consistent flow of information with their key users. They believe their success heavily relies on on-time information dissemination regarding research activities, market rates, proper stock places and other infrastructural requirements.

Adding further, he said;

“..... we depute inspectors to maintain farmer's registration, test quality, price check and delist firms engaged in low-quality fertilizers, pesticides and seeds".

All these measures are to extend services and to facilitate local farmers and agri-input suppliers.

\subsection{Constraints in achieving the Desired Extent of SCI}

Once it was probed that why public sector stakeholders remained unable to attain the desired extent of integration, three major hurdles were emphasized, i.e. scarcity of resources, limited access to updated technologies, and lack of willingness on the part of both the growers and input suppliers to make use of the facilities provided by the Government of Pakistan. Additionally, lack of trust and motivation, high illiteracy, communication gap, limited funds, etc. were highlighted as hurdles to attain desired results.

\subsection{Supply Chain Integration and its Impact on Supply Chain Performance}

The performance management index proposed by Dweiri and Khan (2012) was used to measure the 
impact of SCI on SCP. To comprehend the picture, few glimpse are presented below;

“..... efforts are paying off and the same is evident from the quality and surplus production of multiple crops, fruits and vegetables" [Director General Agriculture Policy Institute (API)].

" ..... I can confidently claim that [due to consistent trainings], today, our growers are capable to meet international standards, rejection rate [has] significantly reduced, and our exports increased [Assistant Director Agriculture (Research)].

“..... logistical protocols are independently managed, so it sometimes, affects the profits inversely"[Deputy Director, Agriculture (Extension \& AR)].

“..... farmers in Pakistan, don't stock much, as they can't afford [due to perishability], hence, serious efforts needed to build storage [cold chains] to avoid wastages, ensure inventory turnover and to reduce lead time [GM Field Wing (PASSCO)].

"Despite of all efforts, channel members inability to comply and/or distrust [on public offices] surely damage overall performance [Economic Consultant, Economic Wing]"

Though, above comments give some insights, however, financial gain is the ultimate predictor of the overall performance. Unfortunately, no solid (quantitative) or measureable outcomes can be extracted from the discussions, however, general statistics (like, 3.81\% growth for the year 2017-18 compared to previous year's $2.07 \% \& 0.15 \%$ for the year $2016-17 \& 2015-16$, speak favorable.

\section{Conclusion}

To our utmost knowledge, this study is among rare studies, wherein, the role of public sector stakeholders in collaborating with their supply chain partners, i.e. growers/farmers and input suppliers has been identified. Based on inputs from the interviewers, this study provides some significant and useful insights. Firstly, to attain desirous performance, SCI across AFVC is inevitable. Secondly, SCI is observed as a contextual phenomenon, and it's not less than a theoretical myth that only the utilization of higher intensity of SCI leads to higher supply chain performance. Thirdly, the extent of SCI can practically be measured on three possible extents, i.e. strategic, tactical and operational. Lastly, desirous performance can be attained through active involvement of supply chain actors, activities and resources.

Furthermore, the results highlight that public sector stakeholders are using multiple means to share all possible resources, including, personal, financial, physical and informational with their supply chain partners. Despite of limitations, there are a number of agri-based collaborative projects which can be marked as 'integration landmarks', for example, the Kitchen Gardening Program, Punjab IrrigatedAgriculture Productivity Improvement Project, National Program for Improvement of Water Courses, High-Efficiency Irrigation System, etc. Similarly, the efforts of public sector stakeholders are highly appreciable especially for establishing mechanisms for sharing useful information and research output both with growers and input suppliers. The efforts are not limited to information sharing rather agripartners are collectively engaged in joint decision making and collaborative projects. Interestingly, the extent of integration varies significantly among activities, resources, and actors, and that's how the outcomes of this study add valuable insight in the existing series of supply chain literature especially regarding network perspective.

Considering the significance of networks, most of the researchers, like, (Anderson et al., 1994; Koops et al., 2002; Ritter \& Gemünden, 2004) have stated the need for effective management of key network factors and interaction between these to generate better positives. The outcomes of this study confirms that different extents of integration are required along various supply chain activities to generate overall supply chain performance. This understanding is somehow in line with the research work of Flynn et al. (2010), wherein, different configurations and arcs of SCI have been suggested. Similarly, as per contingency perspective, where manufacturers make use of a certain extent of integration with a desire of harmonizing the particular SCI and the environment in which it is utilized (Flynn et al., 2010; Wiengarten et al., 2016), this study also advocates that blind use of high level of SCI, without 
considering contextual factors, may not generate desirous performance. Finally, this study considered the need for implementing the required extent of SCI beyond the dyadic level, to the network level. This was prescribed, because of the ever-rising need for establishing the productive AFVC's specifically in developing countries in a desire to expand agriculture output.

The comparison of given studies' results with those of others, clearly revealed that one can't overestimate the role of SCI in causing SCP. The effect of SCI on performance can only be examined, if all the contingencies and configurations are kept under consideration. Else, the use of SCI can backfire, in the form of unprecedented cost, resulting in losses for firms in particular and overall supply chains as a whole. Moving forward, the outcomes of this study strengthened the preposition that SCI is a contextual phenomenon. This study considered AFVC of Pakistan, with an assumption, that it is one of the most segregated and critical value chains of all, and universal (high level) implementation of SCI must not be useful in all cases. A number of contextual factors, like a variety of players involved, perishability and nature of the product, the unpredictability of weather and instability in governmental policies, etc. may demand different extent of integration among actors, activities and resources of the supply chain network.

This study extends managerial understanding regarding appropriate levels of SCI among supply chain partners. More specifically, understanding the required extent of SCI can assist firms and supply chain partners to save their energies and resources for future gains. Like others, this study also has some limitations, which set the tone for futuristic researches in the field of SCI. Future researchers can consider a longitudinal data, which may give them more comprehensive insights. The geographical (Pakistan) and sectorial (agriculture) scope may raise questions on the generalizability of the results. Hence, knowing the current and required extent of integration by studying diversified sectors across multi-echelons supply chains can help to generalize the results. Similarly, quantitative frameworks grounded from literature, hypothesizing SCI and SCP and empirical verifications can produce deeper and valuable insights.

\section{References}

Anderson, J. C., Håkansson, H., \& Johanson, J. (1994). Dyadic business relationships within a business network context. Journal of marketing, 58(4), 1-15.

Autry, C. W., Rose, W. J., \& Bell, J. E. (2014). Reconsidering the supply chain integration-Performance relationship: In search of theoretical consistency and clarity. Journal of Business logistics, 35(3), 275-276.

Barnes, B. R., Naudé, P., \& Michell, P. (2007). Perceptual gaps and similarities in buyer-seller dyadic relationships. Industrial Marketing Management, 36(5), 662-675.

Bechtel, C., \& Jayaram, J. (1997). Supply chain management: a strategic perspective. The International Journal of Logistics Management, 8(1), 15-34.

Birthal, P. S., Joshi, P. K., \& Gulati, A. (2005). Vertical coordination in high-value commodities: Implications for smallholders. Retrieved from

Childerhouse, P., \& Towill, D. R. (2011). Arcs of supply chain integration. International Journal of Production Research, 49(24), 7441-7468.

Christensen, P. R., \& Klyver, K. (2006). Management consultancy in small firms: how does interaction work? Journal of Small Business and Enterprise Development.

Christopher, M. (2016). Logistics \& supply chain management: Pearson UK.

Cousins, P. D., \& Menguc, B. (2006). The implications of socialization and integration in supply chain management. Journal of Operations Management, 24(5), 604-620.

Cravens, D. W., \& Piercy, N. F. (1994). Relationship marketing and collaborative networks in service organizations. International Journal of Service Industry Management, 5(5), 39-53.

Davis, T. (1993). Effective Supply Chain Management, Sloan Mgmt: Rev. 
de Keizer, M., Akkerman, R., Grunow, M., Bloemhof, J. M., Haijema, R., \& van der Vorst, J. G. (2017). Logistics network design for perishable products with heterogeneous quality decay. European Journal of Operational Research, 262(2), 535-549.

Devaraj, S., Krajewski, L., \& Wei, J. C. (2007). Impact of eBusiness technologies on operational performance: the role of production information integration in the supply chain. Journal of Operations Management, 25(6), 1199-1216.

Doering, T., De Jong, J., \& Suresh, N. (2019). Performance effects of supply chain integration: The relative impacts of two competing national culture frameworks. Cogent Business \& Management, 6(1), 1610213.

Dweiri, F., \& Khan, S. A. (2012). Development of a universal supply chain management performance index. International Journal of Business Performance and Supply Chain Modelling, 4(3-4), 232245.

Ellinger, A. E., Keller, S. B., \& Hansen, J. D. (2006). Bridging the divide between logistics and marketing: facilitating collaborative behavior. Journal of Business logistics, 27(2), 1-27.

Ellram, L. M., \& Cooper, M. C. (2014). Supply chain management: It's all about the journey, not the destination. Journal of Supply Chain Management, 50(1), 8-20.

Fawcett, S. E., \& Magnan, G. M. (2002). The rhetoric and reality of supply chain integration. International Journal of Physical Distribution \& Logistics Management, 32(5), 339-361.

Flynn, B. B., Huo, B., \& Zhao, X. (2010). The impact of supply chain integration on performance: A contingency and configuration approach. Journal of Operations Management, 28(1), 58-71.

Frohlich, M. T., \& Westbrook, R. (2001). Arcs of integration: an international study of supply chain strategies. Journal of Operations Management, 19(2), 185-200.

Ganbold, O., Matsui, Y., \& Rotaru, K. (2020). Effect of information technology-enabled supply chain integration on firm's operational performance. Journal of Enterprise Information Management.

Germain, R., \& Iyer, K. N. (2006). The interaction of internal and downstream integration and its association with performance. Journal of Business logistics, 27(2), 29-52.

Graham, G., Zailani, S., \& Rajagopal, P. (2005). Supply chain integration and performance: US versus East Asian companies. Supply Chain Management: An International Journal.

Green, K., \& Inman*, R. (2005). Using a just-in-time selling strategy to strengthen supply chain linkages. International Journal of Production Research, 43(16), 3437-3453.

Halinen, A., \& Törnroos, J.- $\AA$. (2005). Using case methods in the study of contemporary business networks. Journal of Business Research, 58(9), 1285-1297.

Handfield, R. B., \& Nichols, E. L. (2002). Supply chain redesign: Transforming supply chains into integrated value systems: FT Press.

Harland, C. M. (1996). Supply chain management: relationships, chains and networks. British Journal of management, 7(s1).

Hendijani, R., \& Saei, R. S. (2020). Supply chain integration and firm performance: the moderating role of demand uncertainty. Cogent Business \& Management, 7(1), 1760477.

Jarillo, J. C. (1988). On strategic networks. Strategic management journal, 9(1), 31-41.

Jarosz, L. (2000). Understanding agri-food networks as social relations. Agriculture and human values, 17(3), 279-283.

Jraisat, L. (2016). A network perspective and value added tasks: the case of agri-food value chain. Asia Pacific Journal of Marketing and Logistics, 28(2), 350-365.

Kahn, K. B., \& Mentzer, J. T. (1998). Marketing's integration with other departments. Journal of Business Research, 42(1), 53-62.

Koops, S., Mollenkopf, D., \& Zwart, T. (2002). Food supply chains: Are efficiency and responsiveness mutually exclusive? Journal on chain and network science, 2(1), 7-18.

Kostova, T., \& Roth, K. (2002). Adoption of an organizational practice by subsidiaries of multinational corporations: Institutional and relational effects. Academy of management journal, 45(1), 215233. 
Kusi-Sarpong, S., Sarkis, J., \& Wang, X. (2016). Assessing green supply chain practices in the Ghanaian mining industry: A framework and evaluation. International Journal of Production Economics, $181,325-341$.

Lee, H. L., \& Billington, C. (1992). Managing supply chain inventory: pitfalls and opportunities. Sloan management review, 33(3), 65-73.

Leuschner, R., Rogers, D. S., \& Charvet, F. F. (2013). A meta-analysis of supply chain integration and firm performance. Journal of Supply Chain Management, 49(2), 34-57.

Li, W., \& Chen, J. (2018). Backward integration strategy in a retailer Stackelberg supply chain. Omega, 75, 118-130.

Liu, W., Bai, E., Liu, L., \& Wei, W. (2017). A framework of sustainable service supply chain management: A literature review and research agenda. Sustainability, 9(3), 421.

Lui, S. S., Wong, Y.-y., \& Liu, W. (2009). Asset specificity roles in interfirm cooperation: Reducing opportunistic behavior or increasing cooperative behavior? Journal of Business Research, 62(11), 1214-1219.

Mackelprang, A. W., Robinson, J. L., Bernardes, E., \& Webb, G. S. (2014). The relationship between strategic supply chain integration and performance: a meta-analytic evaluation and implications for supply chain management research. Journal of Business logistics, 35(1), 71-96.

Mentzer, J. T., DeWitt, W., Keebler, J. S., Min, S., Nix, N. W., Smith, C. D., \& Zacharia, Z. G. (2001). Defining supply chain management. Journal of Business logistics, 22(2), 1-25.

Mentzer, J. T., Flint, D. J., \& Hult, G. T. M. (2001). Logistics service quality as a segment-customized process. Journal of marketing, 65(4), 82-104.

Mikkola, M. (2008). Coordinative structures and development of food supply chains. British Food Journal, 110(2), 189-205.

Mohamed, E., \& Hassan, A. (2019). How Does Complexity Affect the Relationship Between Supply Chain Integration and Firm Performance?: A Conceptual Framework. International Journal of Service Science, Management, Engineering, and Technology (IJSSMET), 10(2), 22-37.

Morash, E. A., \& Clinton, S. R. (1998). Supply chain integration: customer value through collaborative closeness versus operational excellence. Journal of Marketing Theory and Practice, 6(4), 104120.

Narasimhan, R., \& Das, A. (2001). The impact of purchasing integration and practices on manufacturing performance. Journal of Operations Management, 19(5), 593-609.

Oliver, R. K., \& Webber, M. D. (1982). Supply-chain management: logistics catches up with strategy. Outlook, 5(1), 42-47.

Porter, M. E. (1985). Competitive advantage: creating and sustaining superior performance. 1985: New York: Free Press.

Power, D. (2005). Supply chain management integration and implementation: a literature review. Supply Chain Management: An International Journal.

Rehman, S. T., Khan, S. A., Kusi-Sarpong, S., \& Hassan, S. M. (2018). Supply chain performance measurement and improvement system: a MCDA-DMAIC methodology. Journal of Modelling in Management, 13(3), 522-549.

Ritter, T. (1999). The networking company: antecedents for coping with relationships and networks effectively. Industrial Marketing Management, 28(5), 467-479.

Ritter, T., \& Gemünden, H. G. (2004). The impact of a company's business strategy on its technological competence, network competence and innovation success. Journal of Business Research, 57(5), 548-556.

Schoenherr, T., \& Swink, M. (2012). Revisiting the arcs of integration: Cross-validations and extensions. Journal of Operations Management, 30(1-2), 99-115.

Shou, Y., Li, Y., Park, Y. W., \& Kang, M. (2017). The impact of product complexity and variety on supply chain integration. International Journal of Physical Distribution \& Logistics Management, 47(4), 297-317.

Sluyts, K., Matthyssens, P., Martens, R., \& Streukens, S. (2011). Building capabilities to manage strategic alliances. Industrial Marketing Management, 40(6), 875-886. 
Song, G., Song, S., \& Sun, L. (2019). Supply chain integration in omni-channel retailing: a logistics perspective. The International Journal of Logistics Management, 30(2), 527-548.

Soto-Silva, W. E., Nadal-Roig, E., González-Araya, M. C., \& Pla-Aragones, L. M. (2016). Operational research models applied to the fresh fruit supply chain. European Journal of Operational Research, 251(2), 345-355.

Stank, T. P., Keller, S. B., \& Daugherty, P. J. (2001). Supply chain collaboration and logistical service performance. Journal of Business logistics, 22(1), 29-48.

Stevens, G. C. (1989). Integrating the supply chain. International Journal of Physical Distribution \& Materials Management, 19(8), 3-8.

Tarifa-Fernandez, J., \& De Burgos-Jiménez, J. (2017). Supply chain integration and performance relationship: a moderating effects review. The International Journal of Logistics Management.

Turkulainen, V. (2008). Managing cross-functional interdependencies-the contingent value of integration: Teknillinen korkeakoulu.

Visnjic, I., Wiengarten, F., \& Neely, A. (2016). Only the brave: Product innovation, service business model innovation, and their impact on performance. Journal of product innovation management, 33(1), 36-52.

Wiengarten, F., Li, H., Singh, P. J., \& Fynes, B. (2019). Re-evaluating supply chain integration and firm performance: linking operations strategy to supply chain strategy. Supply Chain Management: An International Journal.

Wilson, D. T. (1995). An integrated model of buyer-seller relationships. Journal of the Academy of marketing Science, 23(4), 335-345.

Wong, C. Y., Boon-Itt, S., \& Wong, C. W. (2011). The contingency effects of environmental uncertainty on the relationship between supply chain integration and operational performance. Journal of Operations Management, 29(6), 604-615.

Yin, R. (2003). Case study research: design and methods,(3rd) Sage Publications. Thousand Oaks, California, 2278-0181.

Yin, R. K. (2015). Qualitative research from start to finish: Guilford Publications.

Zhao, X., Huo, B., Selen, W., \& Yeung, J. H. Y. (2011). The impact of internal integration and relationship commitment on external integration. Journal of Operations Management, 29(1-2), 17-32. 